\title{
Hydrotropism in Roots of Lupinus albus.
}

\author{
BY \\ HENRY D. HOOKER, JR. \\ Osborn Botanical Laboratory, Yale University, New Haven, Connecticut.
}

\section{INTRODUCTION.}

SINCE it was shown in a previous paper (16) that the phenomena com$S$ monly called thermotropic in roots were due largely to hydrotropism, it seemed advisable to investigate this tropism more in detail, and to determine to some extent the laws which govern it, and the limits within which it acts. The subject is of more particular interest because the question of the limitation of hydrotropic sensitivity to the root-tip has never been definitely settled since Darwin first suggested it. The work was done for the most part during the summer semester of 1913 at the University of Strassburg under the guidance of Professors Jost and Kniep, whose invaluable assistance I wish to acknowledge here. The work was finished at the Osborn Botanical Laboratory of Yale University at New Haven, Connecticut, under Professor Evans, to whom I am likewise indebted for much help.

\section{HISTORY.}

The idea that roots enter the earth to seek moisture necessary for growth is one of those popular conceptions that are of venerable age because they are easily and naturally thought of. It was consequently offered as an explanation of those phenomena which we now call geotropic. Later, when botanists began to comprehend the nature of this latter reaction, the possibility of hydrotropism was questioned and experiments made which seemed to disprove its existence, for these two tropisms were then thought to be alternative. The study of hydrotropism has therefore experienced but slow development amid numerous set-backs, although its history has been relatively long.

As early as 1700 Dodart (7) tried to explain the directions taken by the root and shoot, as determined by the materials they need. He thought roots were made of fibres which shortened when acted on by the earth's moisture and lengthened when warmed by the sun's rays, while the stem

[Annals of Botany, Vol XXIX. No. CXIV. April, 1915.] 
fibres acted in exactly the reverse manner. Thus roots bent down and stems up.

Half a century later, Bonnet (1, p. 272) recorded an instance of hydrotropism when he admired the movement of roots which follow the undulations of a wet sponge.

Duhamel (9, vol. i, p. 86 ; vol. ii, pp. I37-45) was led to believe that large bodies of water might influence the direction assumed by the roots of near-by trees. To decide this, he made experiments. He placed an acorn upside down between two sponges, and again in pipes filled with earth and laid at various angles. As the radicle grew down and the plumule up in every case, Duhamel concluded that moisture had no effect on the directions assumed by the root and shoot.

Just a century after Dodart, Erasmus Darwin (5, p. I44) wrote: 'The plumula is stimulated by air into action and elongates itself where it is most excited, and the radicle is stimulated by moisture and elongates where it is most excited.'

The following year, Lefébure (21, p. 50) demonstrated nicely the existence of hydrotropism, although he did not realize it. A moist sponge was placed over some seeds in a nutshell, which was then inverted. The roots grew down and soon reached the air, whereupon they turned back into the sponge.

Knight (20), in an article read before the Royal Society ten years later, gave the first complete proof of hydrotropism in roots. Vicia Faba seeds were half embedded in the mould of inverted flower-pots. The radicles of the germinating seedlings had earth above and air below them. When the mould was kept moderately moist, the radicles extended horizontally along the under surface of the mould and sent side rootlets up into it. When the earth was supersaturated with moisture, the roots grew straight down into the air beneath. Knight held to the physical explanation of Dodart and E. Darwin, and emphatically denied the existence of anything resembling sensation or intellect in plants.

In endeavouring to test E. Darwin's statement, Keith (19) substantially repeated Duhamel's experiment. He used a kidney bean and a grain of wheat planted upside down in a glass tube. Although the radicles assumed a horizontal position after descending perpendicularly into the open air below the mould in the tube, Keith passed over this fact, because germination was then past. He merely wished to show that the primary cause of the descent of the radicle at germination was not sensitiveness to moisture.

In I 824 Dutrochet (10, pp. 59-60) made several experiments, including a repetition of Keith's, with Phaseolus multiflorus. He distinguished carefully between mass and moisture. In one experiment he fastened beans to the roof of an excavation where the earth above them was several metres thick. As the roots bent down, he concluded that mass of itself had no 
influence. Vicia Faba seedlings were suspended near the surface of a wet sponge. The air was saturated and the roots did not bend, so Dutrochet decided that hydrotropism did not exist.

Five years later Johnson (17) was aroused likewise by E. Darwin's brief statement to test the influence of moisture on roots. An iron wire ring, on which was stretched some netting, was fixed in the mouth of an ale glass, filled with garden mould, and sown with mustard seeds. As the air at the bottom of the glass became moist from contact with the damp earth, the radicles grew straight down into it. A hoop was furnished with a thread-net bottom, filled with moist soil, and sown with mustard seed. As soon as the radicles penetrated the earth and the net, they turned to one side and crept along the under surface, perforating the net several times. $\mathrm{He}$ observed the same result when the seeds were placed in the pores of a sponge, fixed in the mouth of an inverted ale glass and cut off flush with the brim. Johnson concluded that roots were endowed with some force, different from and more powerful than that of gravitation, which compelled them to seek moisture.

Duchatre $(8$, p. 384$)$ in $185^{6}$ gave a detailed criticism of the work of his predecessors. He experimented with Chrysanthemum, Hydrangea, and Veronica, and found that by keeping the air saturated and the soil dry, adventitious roots developed around the base of the stem and showed no tendency to descend to earth. Several roots came out of the earth and lay on the surface or even ascended into the moist air.

Van Tieghem $(32$, p. 325$)$ in 1869 explained the direction taken by germinating pollen tubes as due to their sensitiveness to moisture. 'The pollen tubes finding moisture on only one side, bend in that direction and penetrate the stigma.' The statement was copied by Capus (2, p. 282) nine years later.

Ciesielski $(3$, p. 25 , fig. 5$)$ in I 87 I observed that a Zea Mays root laid horizontally on a water surface, which wets the under side only, bends upward in the usual bending zone. The same thing resulted over a wet solid surface, and could be obtained with oat and wheat seedlings as well. Ciesielski considered this upward bending to be a phenomenon of growth which illustrated a peculiar theory that he was advancing.

Sachs (27) reinvestigated the entire field of hydrotropism and placed it on a firm and substantial basis. He experimented with roots of Pisum, Phaseolus, Vicia, Zea, Helianthus, Tropaeolum, and Ipomaea, and always took the precaution of working in a dark room. He found a hanging sieve with zinc sides and a cloth bottom the most satisfactory means of obtaining hydrotropic bending. It was filled with moist sawdust, sown with seed, and hung at an angle of $45^{\circ}$. The results agreed with those of Knight and Johnson. By hanging the sieve at an angle the projecting root was subjected to a difference of moisture on the two sides, and so bent to that part 
of the sieve-bottom nearest it. Sachs mentions several less satisfactory substitutes for the sieve, such as peat bricks, plaster of Paris plates, sponges, or bags of moist earth. His attempt to explain hydrotropism as caused by thermotropism failed (see 16, pp. I35-6), so he was forced to conclude that the bending was produced directly by the moisture difference. Duchatre's and Ciesielski's results he considered to be produced by alterations in the turgidity of the roots. Shoots were found to be hydrotropically insensitive, for they grew straight out of the sawdust in the tilted sieves.

Van Tieghem (33) in 1876 observed the formation of arcades by the stolons which give rise to sporangiophores in Absidia, and attributed their bending to 'somatropism' or the attraction of mass. He found stolons of Circinella, Mortierella, Mucor, Pilobolus, and Phycomyces all positively somatropic. Three years later Sachs (28, p. 224) showed Van Tieghem's somatropism to be untenable. He suggested that the vegetative hyphae of Phycomyces and Mucor were positively, and their sporangiophores negatively, hydrotropic.

Charles Darwin (4, pp. 180-6) held that the hydrotropic sensitivity of radicles resided in their tips. He used Sachs' method for obtaining the bending with seedlings of Phaseolus, Vicia, Avena, and Triticum. To check the bending, from one to two millimetres of the root-tip were coated with a mixture of olive oil and lamp-black. Of fifty-nine roots so treated, twenty-nine remained straight. One millimetre of the tip was cauterized with silver nitrate in other experiments. Of twenty cauterized roots, eleven remained straight after twenty-four hours. Darwin wrote that 'a greater number of experiments than those which were actually tried would have been necessary had it not been clearly established that the tip of the radicle is the part which is sensitive to various other irritants'.

Wiesner (35, pp. I30-4) objected to Darwin's method, on the ground that the roots were in an abnormal condition. His own experiments with decapitated roots led him to the conclusion that hydrotropic sensitivity was not confined to the root-tip. The term 'hydrotropism' appears here for the first time in the literature.

Detlefsen (6, pp. 646-7) also criticized Darwin's method and results. An experiment with six decapitated pea seedlings, four of which reacted, convinced him that the entire growing region of the root perceived the stimulus.

Mer (22) offered a 'more natural' explanation for hydrotropism. After detailed observations on germinating lentil seedlings, he decided that roots were pulled to one side by the attachment of root-hairs, and that they possessed no special hydrotropic faculty.

The same year Wortmann (36, pp. 368-74) showed that Phycomyces nitens sporangiophores were negatively hydrotropic. A sporangiophore projecting through a hole in a glass plate was found to bend away from 
a wet piece of cardboard, but to grow straight by a dry piece. The mycelium was not found to be hydrotropic.

In 1883 Molisch (24) published a comprehensive work on hydrotropism. $\mathrm{He}$ constructed the funnel apparatus for obtaining hydrotropic bendings. The projecting root-tips of seedlings placed on the top of the solid plaster of Paris funnel bend first down and then inward to the moist side of the funnel. Molisch demonstrated that hydrotropic bending resulted from unequal growth of the opposite sides of the root. Roots of $Z e a$ and Pisum seedlings were marked with ink every millimetre, and the region of hydrotropic bending was thereby found to be the growing region. Reactions were inhibited below the minimum temperature for growth. Hydrotropically bent roots were plasmolysed, and remained bent, showing that the reaction was not a phenomenon of turgidity. He observed that disturbances of the turgidity caused by a psychrometrical difference frequently bent the root away from the source of moisture. Molisch agreed with Darwin that the root-tip alone received the hydrotropic stimulus, and gave positive proof that $\mathrm{I} \cdot 5 \mathrm{~mm}$. of the root-tip was sensitive. The part of the root above the tip was wrapped in wet tissue-paper, and the wrapping was shoved down as the root grew, so that more than $\mathrm{I} \cdot 5 \mathrm{~mm}$. was never exposed to the moisture difference. Molisch found side rootlets especially sensitive to hydrotropism. The rhizoids of Marchantia polymorpha, Lumularia, and Fegatella were found to be positively hydrotropic; the sporangiophores of Mucor and Coprinus and the hypocotyl of Limum usitatissimum were shown to be negatively hydrotropic.

Elfving (12) in I 890 observed that sporangiophores of Phycomyces nitens bent towards pieces of iron and various other substances, and described the process as physiological action at a distance. Two years later Errera (14) pointed out that all of these substances were hygroscopic, so that the real cause of the bending was negative hydrotropism. He found that roots bent away from iron even in a saturated atmosphere, 'which shows that hydrotropism is not due, as generally admitted, to differences in the hygrometric state of the air. Hydrotropism itself is the bending of a plant towards a point, not where it will find a minimum or maximum of moisture, but where it will, within certain limits, transpire most or least.' Elfving (13) replied in 1893 that potash, although hygroscopic, did not cause the sporangiophores to bend, and that various other inactive substances were rendered active by exposure to sunlight or to heat. Errera (15) wrote in 1905 that although sure of the exactness of his former experiments, Elfving's more recent experiments should be repeated in the light of our recent knowledge concerning the radiation of metals.

In 1894 Miyoshi (23) demonstrated that pollen tubes of Epilobium angustifolium, Oenothera biennis, Oe. fructicosa, Digitalis grandiflora, and $D$. purpurea were positively hydrotropic. 
The same year Rothert (26) published a critical study of the literature on the function of the root-tip. He pointed out that Darwin's theory was as yet unproved. The converse of Molisch's experiment would determine the point, however. This had been done in Pfeffer's laboratory, but as no details were given definite conclusions could not be drawn in view of numerous possible sources of error.

In I90I Steyer (31) thoroughly investigated the hydrotropism of Phycomyces nitens. He found that the sporangiophores were both negatively and positively hydrotropic according to the percentage of relative moisture. Steyer was unable to find any foundation for Elfving's 'physiological action at a distance'. Older sporangiophores were found to be more sensitive than younger ones, and exposure to light lessened their sensitivity.

Voechting (34, pp. 98-102) in 1902 experimented with potato sprouts and decided that they were hydrotropic. The following year Singer (29) showed that Voechting's results were probably due to impure laboratory air, and that potato sprouts were not hydrotropic.

Sperlich (30) in 1908 observed that the stolon of Nephrolepis was positively hydrotropic, thus enabling it to reach a moist substratum in spite of the absence of geotropism.

The last contribution to the literature on hydrotropism was made by Jost and Stoppel (18, p. 210) in 1912, and dealt with the limitation of hydrotropic sensitivity to the root-tip. Of eighteen decapitated Lupinus albus roots arranged a few millimetres from a wet filter-paper, thirteen bent to the paper. This indicates that although the strongest hydrotropic sensitivity resides in the tip, it is not confined to it.

$\mathrm{Up}$ to the present time hydrotropism has been found in the sporangiophores of various fungi, in the rhizoids of hepatics, in roots and pollen tubes, and in rare cases in the hypocotyl of the spermatophytes.

\section{EXPERIMENTAL PART.}

I. Method. The simplest contrivance for obtaining hydrotropic bending in roots was constructed in the following manner: A glass plate covered on both sides with wet filter-paper was inserted in a small rectangular glass jar parallel with the longer sides. Roots were fastened to pins which pierced strips of cork at regular intervals. Two strips were laid across the top of the jar on either side of the glass plate and parallel with it. The roots thus brought into the jar were exposed on one side to the moisture of the filter-paper, and their distance from the paper could readily be controlled. The bottom of the jar was covered with water to keep the filter-paper wet and to prevent the roots from drying out. The jar was left open that the air in it might not become saturated and so prevent 
a psychrometrical difference about the roots. For relatively rough work this method was found very effective.

In order to make careful measurements a more complicated apparatus was constructed. A zinc vessel $10 \mathrm{~cm}$. broad, $20 \mathrm{~cm}$. high, and $30 \mathrm{~cm}$. long was used. The sides were of glass, and were covered with flaps of black paper to shut out the light in case the experiment was not made in a dark room. The box was supplied with a tightly fitting cover. One end of the vessel was covered on the inside with filter-paper. On the floor $2 \mathrm{~cm}$. from this end, a piece of glass $2 \mathrm{~cm}$. high and $10 \mathrm{~cm}$. long was fixed upright and the connexions with the sides and bottom were made water-tight. This formed a reservoir, which collected water at the base of the filterpaper. Two short tubes penetrated the zinc wall behind the filter-paper, one near the top, which served as an inlet, and one near the bottom, which acted as an overflow from the reservoir. The former could be connected with the faucet and running water supplied to the filter-paper from above, which flowed down it to the reservoir at its base and made its exit through the lower opening. In the earlier experiments the water could not safely be left running, so a constant supply of water was obtained by other means. A bent glass tube, the lower end of which was drawn out to a capillary, supplied water from a beaker. By breaking off the capillary at the proper point, the amount of water supplied could be perfectly regulated. In this way a constant source of moisture was produced at one end of the closed compartment. The air within never became completely saturated, although the cover was kept on. This ensured a definite decrease in the percentage of relative moisture from one end to the other. This decrease could be augmented or diminished by placing at the drier end of the compartment a tray filled with sulphuric acid or water respectively. Mouldings extended the length of the two sides about $2 \mathrm{~cm}$. from the top. These supported strips of cork to which seedlings had been pinned, which could thus be placed at any desired distance from the filter-paper. Evaporation from the cotyledons was found to have considerable influence on the prevailing moisture conditions, so a method was devised to obviate it. Zinc trays were constructed $9.5 \mathrm{~cm}$. long, $2 \mathrm{~cm}$. wide, and $3 \mathrm{~cm}$. deep. These had covers, and were arranged to hang from the mouldings on the opposite sides of the compartment. Five holes were made in the bottom of the trays, through which the roots of the seedlings were inserted or allowed to grow. The cotyledons were packed with moist sawdust, with which the trays were completely filled. The bottom of the tray was coated on the outside with paraffin that any hygroscopic action of the zinc might be avoided. In this way only the roots which were to be acted on hydrotropically came under the artificial conditions of the zinc compartment. The flank sides of the roots were turned towards the filter-paper. 
Specially constructed hygrometers were used to measure the percentages of relative moisture within the zinc compartment. A grain of Stipa pennata was inserted in a small cork and the awn was cut off at an appropriate distance, leaving from $\mathrm{I} \mathrm{cm}$. to $2 \mathrm{~cm}$. of it projecting vertically from the cork. A glass capillary about $2 \mathrm{~cm}$. long was fixed with sealing-wax to the cut end of the awn so that it extended horizontally. This served as an indicator, turning as the hygroscopic awn twisted tighter. Markings were made on a circular piece of cardboard fastened to the top of the piece of cork. This hygrometer was calibrated by placing it in a small closed compartment with a relatively large amount of a definite concentration of sulphuric acid. The percentage of relative moisture was determined by the vapour pressure of the sulphuric acid.

\section{TABLE I. ${ }^{1}$}

\begin{tabular}{|c|c|c|}
\hline $\begin{array}{c}\text { Percentage } \\
\text { of } \\
\mathrm{H}_{2} \mathrm{SO}_{4} .\end{array}$ & $\begin{array}{l}\text { Vapour } \\
\text { pressure } \\
\text { at } 20^{\circ} \mathrm{C} \text {. }\end{array}$ & $\begin{array}{l}\text { Relative } \\
\text { percentage of } \\
\text { moisture } \\
\text { approximately. }\end{array}$ \\
\hline $57 \cdot 65$ & $3 \cdot 728$ & 2 I \\
\hline $5^{2 \cdot 13}$ & $5 \cdot 79^{2}$ & 33 \\
\hline 43.75 & $8 \cdot 494$ & 49 \\
\hline $\begin{array}{l}37.09 \\
33.10\end{array}$ & $\mathrm{I}_{2} \cdot 3 \mathrm{I}_{7}$ & $7 \mathrm{I}$ \\
\hline $24 \cdot 26$ & I 4.482 & 83 \\
\hline 0.00 & $17 \cdot 363$ & 100 \\
\hline
\end{tabular}

By using several different sulphuric acid solutions, the hygrometers could be rendered accurate within 5 per cent., but they had to be recalibrated every three weeks. The instruments were carefully compared with one another and were found to vary from one another within 2 per cent. The measurements of psychrometric differences would then be accurate within 2 or 3 per cent., which is sufficient for the present purposes.

A hygrometer was placed at either end on the floor of the compartment, their centres $25 \mathrm{~cm}$. apart. Under ordinary circumstances a difference of 8 per cent. was registered.

The seeds of Lupinus albus were soaked twenty-four hours in water and allowed to germinate in sawdust until the roots had reached a suitable length. To be sure there are other seedlings which react better to hydrotropism than lupins, as for example corn seedlings. But great difficulty was experienced in obtaining straight roots of corn that would suit for experimentation. In this and other respects lupin seedlings were found to be most satisfactory.

The experiments were conducted for the most part at a temperature of $20^{\circ} \mathrm{C}$.

${ }^{1}$ Compiled from Landolt and Börnstein: Physikalisch-chemische Tabellen, pp. 360, 426. Vierte Auflage. Berlin, I9I 2. 
2. Limits of the reaction. The first point that was investigated was within what limits of relative moisture hydrotropic reactions take place in roots. The upper limit is evidently saturation. The lower limit was found to be determined by the inability of roots to grow in air that is too dry. As no results have been observed in the literature which determined the amount of water vapour requisite for growth, the following experiments were made. A number of Erlenmeyer flasks were fitted with corks, and a hole was bored through each cork. Seedlings about $3 \mathrm{~cm}$. long were selected, and the roots inserted through the hole. Only one root was placed in each flask, as several were found to alter materially the moisture-content of the enclosed air and to have a strong reciprocal influence. The vapour pressure within the flasks was regulated by sulphuric acid solutions. The roots were marked with ink and measured before and after the experiment, to determine the amount of growth during the twenty-four hours. The percentages of relative moisture were calculated from the vapour pressures.

TABLE II.

\begin{tabular}{|c|c|c|c|c|}
\hline $\begin{array}{l}\text { Percentage } \\
\text { of } \mathrm{H}_{2} \mathrm{SO}_{4} \\
\text { in water. }\end{array}$ & $\begin{array}{l}\text { Vapour } \\
\text { pressure. }\end{array}$ & $\begin{array}{c}\text { Relative } \\
\text { percentage of } \\
\text { moisture. }\end{array}$ & $\begin{array}{l}\text { No. of roots } \\
\text { experimented } \\
\text { with. }\end{array}$ & $\begin{array}{c}\text { Average } \\
\text { growth } \\
\text { per hour. }\end{array}$ \\
\hline 0.00 & $I z \cdot O$ & 100 & 30 & $0.75 \mathrm{~mm}$. \\
\hline $7 \cdot 0$ & $16 \cdot 5$ & 95 & 35 & $0.5^{2} \mathrm{~mm}$. \\
\hline I 4.0 & $15^{\cdot 6}$ & 90 & 30 & $0.22 \mathrm{~mm}$. \\
\hline $2 \mathrm{I} \cdot \mathrm{O}$ & 14.7 & ${ }^{8} 5$ & 30 & $0.15 \mathrm{~mm}$. \\
\hline $27 \cdot 0$ & I $3 \cdot 9$ & 80 & 25 & $0.00 \mathrm{~mm}$. \\
\hline
\end{tabular}

In these experiments the cotyledons were left exposed to the laboratory air. If these are kept moist by wrapping them in wet cotton, the average growth per hour is greater, but the roots within the flasks stop growth and dry up if the relative moisture is reduced to 80 per cent. Seedlings grown in a compartment with saturated air may lengthen as much as $1 \cdot 13 \mathrm{~mm}$. per hour.

Reaction to hydrotropic stimuli ceases, however, slightly above 80 per cent. relative moisture; evaporation then becomes so great and growth so slow that loss of turgidity is apt to come into play and to cover the effects of any hydrotropic stimuli, if such are perceived. Roots subjected to a psychrometrical difference at such percentages often bend away from the source of moisture. This is not to be confused with negative hydrotropism, which is not known to exist in roots (18).

3. Intensity of the reaction. The effects of varying the intensity of the hydrotropic stimulus were next investigated. The zinc compartment and the hygrometers made from Stipa pennata grains were used to make the measurements. A noticeable difference in the rate of growth of roots situated at various distances from the filter-paper became evident before hydrotropic bending was observed. Each tray held five roots. 
EXPERIMENT I.

$\begin{array}{cccc}\text { No. of } & \text { Distance from } & \text { Average } & \text { Growth } \\ \text { tray. } & \text { filter-paper. } & \text { groweth. } & \text { per hour. } \\ \text { I } & 5 \mathrm{~cm} . & 16.8 \mathrm{~mm} . & 0.93 \mathrm{~mm} . \\ \text { II } & 10 \mathrm{~cm} . & 11.0 \mathrm{~mm} . & 0.6 \mathrm{Im} \text {. } \\ \text { III } & 15 \mathrm{~cm} . & 8.4 \mathrm{~mm} . & 0.46 \mathrm{~mm} \text {. } \\ \text { IV } & 20 \mathrm{~cm} . & 7.2 \mathrm{~mm} . & 0.40 \mathrm{~mm} .\end{array}$

This experiment covered eighteen hours. One hygrometer $3 \mathrm{~cm}$. distance from the filter-paper measured 97 per cent., and another $28 \mathrm{~cm}$. distant measured 90 per cent. relative moisture. Three roots in I, two each in II and III, and one in IV bent towards the filter-paper. The reaction was observed in I and II at the end of seven hours, and in III and IV half an hour later.

\section{EXPERIMENT II.}

$\begin{array}{cccc}\text { No. of } & \text { Distance from } & \text { Average } & \text { Growth } \\ \text { tray. } & \text { filter-paper. } & \text { growth. } & \text { per hour. } \\ \text { I } & 5 \mathrm{~cm} \text {. } & \text { I } 9.4 \mathrm{~mm} . & 0.97 \mathrm{~mm} . \\ \text { II } & \text { I0 cm. } & \text { I } 7.2 \mathrm{~mm} . & 0.86 \mathrm{~mm} \text {. } \\ \text { III } & \text { I } 5 \mathrm{~cm} . & \text { II.6 mm. } & 0.58 \mathrm{~mm} \text {. } \\ \text { IV } & 20 \mathrm{~cm} . & 6.2 \mathrm{~mm} . & 0.3 \mathrm{~mm} \text {. }\end{array}$

The experiment lasted twenty hours. The hygrometers measured 87 and 98 per cent. respectively. After six hours three in I began to bend, and an hour later four in II, and two each in III and IV, bent towards the filter-paper. The remaining roots grew straight.

\section{EXPERIMENT III.}

$\begin{array}{cccc}\text { No. of } & \text { Distance from } & \text { Average } & \text { Growth } \\ \text { tray. } & \text { filter-paper. } & \text { growth. } & \text { per hour. } \\ \text { I } & 5 \mathrm{~cm} . & \text { I } 8.2 \mathrm{~mm} . & 0.76 \mathrm{~mm} . \\ \text { II } & \text { IO cm. } & \text { II } .0 \mathrm{~mm} . & 0.46 \mathrm{~mm} . \\ \text { III } & \text { I } 5 \mathrm{~cm} . & 8.6 \mathrm{~mm} . & 0.25 \mathrm{~mm} \text {. } \\ \text { IV } & 20 \mathrm{~cm} . & 6.0 \mathrm{~mm} . & 0.25 \mathrm{~mm} \text {. }\end{array}$

This experiment lasted twenty-four hours. The hygrometers measured 88 and 96 per cent. respectively. After six and a half hours three roots in I and two in II and IV bent positively towards the source of moisture.

\section{EXPERIMENT IV.}

$\begin{array}{cccc}\text { No of } & \text { Distance from } & \text { Average } & \text { Growth } \\ \text { tray. } & \text { filter-paper. } & \text { growth. } & \text { per hour. } \\ \text { I } & 5 \mathrm{~cm} . & 17.6 \mathrm{~mm} . & 0.80 \mathrm{~mm} . \\ \text { II } & \text { IO cm. } & 9.8 \mathrm{~mm} . & 0.45 \mathrm{~mm} \text {. } \\ \text { III } & \text { I } 5 \mathrm{~cm} . & 6.2 \mathrm{~mm} . & 0.29 \mathrm{~mm} \text {. } \\ \text { IV } & 20 \mathrm{~cm} . & 3.6 \mathrm{~mm} . & 0.16 \mathrm{~mm} \text {. }\end{array}$

The experiment lasted twenty-two hours. A tray with sulphuric acid (90 per cent.) was placed in the end opposite the filter-paper. The hygrometers measured 83 and 95 per cent. respectively. One root each in I, III, and IV bent positively after seven and a half hours. One root each in III and IV was curved negatively. 
EXPERIMENT V.

$\begin{array}{cccc}\text { No. of } & \text { Distance from } & \text { Average } & \text { Growth } \\ \text { tray. } & \text { filter-paper. } & \text { growth. } & \text { per hour. } \\ \text { I } & 5 \mathrm{~cm} . & \text { I } 8.2 \mathrm{~mm} . & 0.90 \mathrm{~mm} . \\ \text { II } & \text { I0 cm. } & \text { I } 6.0 \mathrm{~mm} . & 0.80 \mathrm{~mm} \text {. } \\ \text { III } & \text { I } 5 \mathrm{~cm} . & 13.3 \mathrm{~mm} . & 0.67 \mathrm{~mm} . \\ \text { IV } & 20 \mathrm{~cm} . & 10.8 \mathrm{~mm} . & 0.54 \mathrm{~mm} .\end{array}$

The experiment was continued twenty hours. A tray with dilute sulphuric acid (Io per cent.) was placed in the dry end of the compartment. The hygrometers measured 88 and 93 per cent. respectively. Only one root (in III) bent towards the filter-paper. The others remained straight.

This last experiment showed that if the hygrometers measured a difference of only 5 per cent., hydrotropic reaction was very nearly eliminated. If this difference was less, no reactions occurred. The hygrometers were $25 \mathrm{~cm}$. apart, so it may be said that a fall of at least 0.2 per cent. in I cm. is necessary to induce hydrotropic reaction. This represents approximately the minimum intensity of the stimulus. If the other extreme is obtained, the roots are affected by changes in turgidity and bend away from the source of moisture as in Experiment IV. The exact point where this occurs could not be determined; the hygrometers were too inaccurate. The phenomenon is familiar, however, and was mentioned by Molisch (24). The optimum reaction was found to be obtained when a psychrometric difference of 0.4 per cent. for every centimetre was measured. This means a difference of but 0.04 per cent. between the opposite sides of a root I $\mathrm{mm}$. thick.

Repeated experiments with the zinc apparatus showed that the roots in tray I bent normally but $20^{\circ}$ to $30^{\circ}$ from the vertical, while those in tray $\mathrm{V}$ bent from $50^{\circ}$ to $60^{\circ}$. To explain this difference a detailed study of the moisture content of the air in the compartment was necessitated. When the compartment was empty the fall in moisture content was found to be more or less uniform. The presence of the roots, however, had a significant influence on this, so that experiments having any bearing on the question had to be made with the roots in their accustomed positions within the zinc box. Water must evaporate from the surface of a root suspended in moist air, unless the air is saturated. Consequently each root acts as a source of moisture and tends to increase the moisture content of the air about it. The same was observed in the experiments made to determine the minimum relative moisture. As a result of this increase, the fall in the relative moisture of the moister end of the zinc compartment, which contained more of the roots during these experiments, was diminished. The data for the following table were collected from ten experiments in which the hygrometers at the two ends of the apparatus measured approximately 98 per cent. and 90 per cent. The relative moisture was then measured by hygrometers at intervals of $5 \mathrm{~cm}$. throughout the entire length of the 
compartment and the average for each position calculated. In every case the experiments were made with the roots in their customary positions.

TABLE III.

$\begin{array}{cc}\text { Distance } & \begin{array}{c}\text { Average } \\ \text { percentage } \\ \text { from the }\end{array} \\ \text { filter- } & \text { moistive } \\ \text { paper. } & \text { moisture } \\ 3 \mathrm{~cm} . & 98 \cdot 2 \\ 8 \mathrm{~cm} . & 97 \cdot 0 \\ \mathbf{1} 3 \mathrm{~cm} . & 96 \cdot 1\end{array}$

$\begin{array}{cc}\text { Distance } & \begin{array}{c}\text { Average } \\ \text { percentage } \\ \text { from the }\end{array} \\ \text { filter- } & \text { relative } \\ \text { paper. } & \text { moisture. } \\ 18 \mathrm{~cm} . & 94.9 \\ 23 \mathrm{~cm} . & 92.7 \\ 28 \mathrm{~cm} . & 90.1\end{array}$

This shows that the fall in moisture is greater at the dry end of the apparatus. The psychrometric difference would consequently be greater there than at the moister end of the compartment, which explains the greater intensity of reaction observed.

The results of numerous experiments similar to those described in detail has been summed up in the following table. Only those roots were considered that reacted, and, moreover, only those in trays I, II, and III, in order that the results might be comparable. The intensity of the stimulus was calculated from the differences measured by the hygrometers at $20^{\circ} \mathrm{C}$. and is expressed in percentages of relative moisture per centimetre. The bending was positive unless otherwise stated, and the averages were reduced to round numbers.

TABLE IV.

Intensity of
stimulus.
0.1
0.2
0.3
0.4
0.5
0.6 and
above

No. of roots
observed.
45
32
86
60
20
34

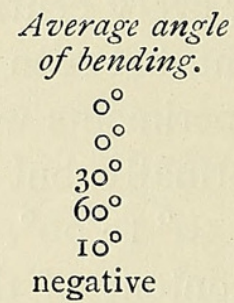

The simpler apparatus for obtaining hydrotropic bending was rotated horizontally about its vertical axis on a clinostat. The action of geotropism was thus eliminated, while the hydrotropic stimulus was in no way affected. Of twenty roots so rotated, seventeen reacted and with the same intensity as the controls. This showed that geotropism was not a factor in determining the intensity of hydrotropic bending.

4. Reaction time. Under optimum conditions, i. e. when the hygroscopic difference near the root is equivalent to a fall of 2 per cent. in $5 \mathrm{~cm}$. and when the absolute amount of moisture is above 90 per cent., roots require six hours to start a hydrotropic reaction. The bending proceeds for one to two hours, whereupon a reaction sets in, and the root-tip regains a vertical position. Under favourable circumstances the entire reaction, from the time when the psychrometric difference is established until the root-tip regains its vertical position, may be completed in eight hours. 
The average time that elapsed before a reaction was visible was seven hours. In case of unfavourable conditions, due to a low stimulus intensity, or to slow growth, ten hours elapsed before bending could be detected.

Roots were exposed to the influence of a moist filter-paper for periods varying from one minute to five hours, in the hope of determining a presentation period such as exists for heliotropism and geotropism. The results were negative as no reaction was obtained unless the roots were exposed more than five hours.

5. Localization of sensitivity. The greatest point of discussion in regard to hydrotropism has been whether the sensitivity is confined to the root-tip or no. Darwin, Molisch, and Pfeffer were of this opinion, while Wiesner, Detlefsen, and Jost gave evidence against the view. By the root-tip is meant one and one-half to two millimetres of the end of the root. Several methods were tried and found unsatisfactory before one was used which decided the question.

Molisch's experiment (24) was repeated, in which roots wrapped up to the tip in wet tissue-paper were exposed to a hydrotropic stimulus. Good results were obtained, although the roots reacted somewhat more slowly than under optimum conditions.

A. Then the converse experiment was made, which Pfeffer had carried out in his laboratory (25). The root-tips alone were covered and the roots then exposed to a psychrometrical difference. Tissue-paper and tin-foil were both used, but the only cases in which bending occurred seemed due rather to pressure of the cap on the root-tip, for the roots bent in all directions.

B. The method used by Jost (18) was next tried, and I.5 to $2 \mathrm{~mm}$. of the tip were carefully removed with a razor. Of fifty-four roots of Lupinus albus which were decapitated, 20 bent towards the filter-paper, I I bent away, and 23 remained straight or bent to one side. The greatest care was used to cut the roots squarely, and the experiment was not begun until some little efficiency had been attained. To the last, nevertheless, a large percentage (20-25 per cent.) of the controls bent in reaction to a wound stimulus. The reaction took place sometimes in two to three hours, and so had clearly no relation to hydrotropism. The results of the experiment were characterized by the greatest irregularity, so that this method was also abandoned.

C. The tips of roots were killed by immersion for two minutes in boiling water, but the rate of growth was seriously diminished, so that no results could be obtained.

D. A rectangular glass vessel was half filled with water. Roots suspended from two parallel cork strips, resting on the rims of the vessel, were immersed for a distance of I to $2 \mathrm{~mm}$. from the apex. Between the two rows of roots, a paraffin trough was fixed at the water 
level, and was filled with a few drops of concentrated sulphuric acid. This produced a psychrometrical difference on the two sides of the roots, which, however, could not be measured as the hygrometers were too large. The whole apparatus was enclosed in a covered jar to obviate disturbing air-currents and placed in a dark cupboard. As the roots grew into the water they were pulled out of it by means of the pins to which they were fastened, and in this way never more than $2 \mathrm{~mm}$. were immersed. Of 94 roots treated in this way, $5^{\circ}$ bent away from the sulphuric acid, 8 towards it, and 36 remained straight or bent to one side. Although these results indicate that hydrotropic reactions may occur if the root-tips do not receive a direct stimulus, they nevertheless were considered unconvincing.

An attempt was made to grow the roots in water first, to accustom them to that medium before the experiment just described was begun, but roots thus grown were found to be very insensitive to hydrotropic stimuli, and the greatest difficulty was met with in obtaining straight roots.

E. The last experiment was repeated, with the difference that paraffin oil was substituted for water in the bottom of the glass vessel. The floating paraffin tray was fixed about $2 \mathrm{~mm}$. from the two rows of immersed root-tips. This apparatus was enclosed in a jar, the air of which was kept as nearly as possible saturated. Of II 7 roots, 8I bent away from the sulphuric acid, $\mathbf{I} 2$ towards it, and the remaining 24 stayed more or less straight. The reactions required eight to nine hours. These results were accepted as decisive.

In discussing the perceptive region of roots, Rothert (26) made four categories to include all possibilities :

I. Only a relatively short tip may be sensitive.

2. The whole end from the growing region to the apex may be sensitive, the tip however to a greater degree.

3. The whole end from the growing region to the apex may be equally sensitive throughout.

4. The whole end except the tip may be sensitive.

The second category has been shown to apply to hydrotropism. Molisch (24) demonstrated that the tip was highly sensitive, and the previous experiment shows that the region above the tip is also capable of receiving hydrotropic stimuli, but since more time was required for the reaction this region is probably less sensitive. The cells appear to lose their hydrotropism in proportion as they lose their embryonic qualities. It seems possible that some connexion may exist here, for differentiation of the root-cells would naturally render them ineffective for other purposes than those for which they become modified.

6. Nature of hydrotropism. Darwin (4) considered hydrotropism to be precisely the opposite of traumatropism, for in the one case the roots bend 
towards the source of moisture, and in the other away from the side wounded. Molisch (24) considered that the roots bent away from the dryness, rather than towards the moisture, and so came to the conclusion that hydrotropism was merely a special kind of traumatropism. That this conception is fallacious is evident by careful examination of the data given. Hydrotropic reactions are obtained best between 90 and 100 per cent. of relative moisture; they cease slightly above 80 per cent.; while roots become noticeably injured from dryness below 80 per cent. If roots are injured, they bend away from the source of moisture, because the turgidity of the exposed side is lost. It is therefore not possible to maintain that hydrotropism is due to reaction from injury. Molisch based his idea on experiments made in an atmosphere of 72 per cent. relative moisture. Without doubt many of the roots sustained injuries.

To gain a correct conception of the nature of hydrotropic reaction in roots, it will be necessary to analyse the factors involved. First will be considered the mechanical effects resulting from exposing a root to a moisture difference in the air. As the root contains more water than the surrounding atmosphere, evaporation will result. This loss of water will produce increased osmotic pressure and decreased turgidity of the root-cells. The length of the cell decreases with the lessening of the turgidity, just as it does before plasmolysis. Since evaporation is greater from one side than from the other, the drier side will shorten more, and the root will bend away from the source of moisture. This reaction was obtained experimentally by pressing seedlings against the vertical surface of an agar block. The air contained 50 per cent. relative moisture. In fifteen minutes II out of 20 root-tips had bent away from the block, and in thirty minutes more all but two had reacted. The controls placed in a saturated atmosphere remained straight. The negative bending described in Experiment IV was of this nature.

But it is still a question if this mechanical tendency to bend negatively is present under those circumstances which produce positive hydrotropic reaction. In order to eliminate the vital factor, which will be discussed presently, roots were anaesthetized by exposing them twenty minutes over 3 per cent. ether water. The roots were then exposed to a hydrotropic stimulus before a moist filter-paper. Of the 25 roots exposed, I 2 bent away from the paper within an hour, and Io more within four hours. Sixteen out of 20 controls reacted hydrotropically. The exposure to ether water rendered the roots hydrotropically insensitive, without stopping their growth. This experiment shows that even those minimal differences of moisture content which induce hydrotropic bending produce a tendency for the root to bend negatively. This is readily explained by considering the mechanical tensions normally present behind the roottips. If a thin radial section of a root, taken 5 to $8 \mathrm{~mm}$. from the tip, is 
divided longitudinally down the middle, the two halves become concave on the inside and bend away from one another, when a drop of water is placed on them. This experiment shows that a region of negative tension is present in the centre of the growing root, and that it is surrounded by a zone of positive tension. In other words, the young root is in a condition of unstable equilibrium. When the positive tension is reduced on one side by evaporation, the root bends.

It has been shown that if roots reacted solely to mechanical forces resulting from a moisture difference, they would bend negatively. That they bent positively can only be explained by assuming the presence of a vital factor, which must be powerful enough to overcome the mechanical factor. The moisture difference produces a difference in the osmotic pressure of the cells on the opposite sides of the root. It is natural to conclude that this difference may cause the bending. If an increased osmotic pressure acts as a stimulus to growth, the explanation of hydrotropism is simple. Moreover, it is known that the growth of certain sea Algae is inhibited by transferring them from salt to fresh water. ${ }^{1}$ Here the decrease in osmotic pressure acts as a stimulus and retards or stops growth. The data in Table II would indicate that this is not the case in roots, but as the roots in these experiments had no means of obtaining water, which is essential for growth, no conclusions may be drawn from them in regard to this question.

In the following experiments roots were exposed to air of various degrees of dryness, in order to produce a stimulus by increasing the osmotic pressure through evaporation. The roots were then placed in moist sawdust, and the amount of growth compared with controls. The amount of relative moisture in the air was determined by using sulphuric acid solutions as in Table II.

Experiment $I$. Forty-seven roots were exposed for four hours in an atmosphere of 85 per cent. relative moisture. After five hours in moist sawdust, the amount of growth was measured and found to average $3 \mathrm{~mm}$. Forty-eight controls were placed for four hours in a saturated atmosphere. The average growth for five hours in moist sawdust was $6.5 \mathrm{~mm}$.

Experiment II. Ninety-six roots were exposed for $4 \frac{1}{2}$ hours to 90 per cent. relative moisture. They averaged for four hours' growth in sawdust $3.6 \mathrm{~mm}$. Eighty roots, after being the same length of time in a saturated atmosphere, averaged $3.7 \mathrm{~mm}$. for four hours' growth in moist sawdust. Eighty-five roots that had been germinated in the sawdust were measured and replaced. They averaged $3.3 \mathrm{~mm}$. for four hours' growth.

Experiment III. Forty-eight roots were placed for one hour in a chamber having a relative moisture of 90 per cent. Their average growth for the following five hours measured $5.3 \mathrm{~mm}$. Forty-eight controls exposed 1 Jost's Pflanzen-Physiologie, p. 348. Dritte Auflage. Jena, I9I4. 
for one hour to a saturated atmosphere averaged $5.25 \mathrm{~mm}$. for five hours in moist sawdust.

These results show that an increase in the osmotic pressure does not stimulate growth directly. Although the vital factor may not be explained so simply, it may yet be stimulated to action by the difference in osmotic pressure. As long as one side of the root has a higher osmotic pressure, there must be a flow of water across the root brought about by diffusion from cell to cell. In each cell there would exist a difference in the osmotic pressure of its two sides, as long as the hydrotropic stimulus lasted. This disturbance of the equilibrium within the cell may be the direct stimulus perceived by the cell as a unit, which produces the differential growth of the opposite sides of the root. The means by which this reaction is carried out are just as mysterious as they are in phototropism and geotropism. It was shown that the root-tip is more sensitive than the rest of the root. This may be connected with the absence of the vacuole in the embryonic cells of the growing point. Their presence would facilitate the establishment of an equilibrium and diminish the effect of a difference in osmotic pressure.

Miss Eckerson (11) has found that, when roots bend after exposure to a difference of temperature on their opposite sides, the cells of the concave side are more permeable than those of the convex side. From this she concludes that heat affects the permeability directly, and that the consequent turgor change offers a mechanical explanation of the curvature. Pfeffer $^{2}$ has shown, however, that temperature can never exercise any marked direct effect on turgidity. Marked alteration taking place in either the osmotic pressure or in the diosmotic properties of the protoplast must be a reaction on the part of the cell to a stimulus, since such changes are regulated by the vital activity of the organism. Moreover, there is an exact parallel between the condition found by Miss Eckerson and that resulting from exposure to a hydrotropic stimulus. The difference of permeability would occasion a flow of water across the root from the concave to the convex side, and a disturbance of the equilibrium within the cells would thus be effected in exactly the same way as by the difference of osmotic pressure in hydrotropically stimulated roots. Therefore the resulting bending would be a reaction to a stimulus identical with that occasioning hydrotropic reactions, and not a mechanical curvature resulting from differences of turgidity. Consequently, so-called thermotropic reactions are largely due to the vital factor discussed in this paper. On account of the environmental conditions to which roots are exposed in thermotropic experiments, the mechanical factor mentioned above cannot play a part.

Since it seemed probable that hydrotropism was in the last analysis osmotropism, the following experiment was made. Two solutions of $I \cdot I 5$

1 Pfeffer's Physiology of Plants, vol. i, p. I 38. Second English edition. Oxford, I9I4. 
per cent. agar were prepared, and to one of them $\mathrm{NaCl}$ was added in the proportion of I.OI $5 \mathrm{gr}$. per IOO c.c. The two solutions were poured into tumblers and allowed to solidify. The agar blocks were then removed, cut smoothly down the middle, and the half blocks paired, so that each tumbler held one half with and one without salt. Of 20 roots placed between these half blocks, I 6 were bent into the salt-free block after seven hours. This reaction would naturally be considered chemotropic, but its analogy to hydrotropism and osmotropism is striking, and raises the question whether many of the results obtained and classed as chemotropic are not in reality of an osmotropic nature. ${ }^{1}$

\section{SUMMARY.}

I. Roots of Lupinus albus are always positively hydrotropic.

2. Hydrotropic reactions occur in roots only between 80 and 100 per cent. relative moisture.

3. The minimum moisture difference to which roots react at $20^{\circ} \mathrm{C}$ is a fall of 0.2 per cent. per $\mathrm{cm}$; the optimum is 0.4 per cent. per $\mathrm{cm}$. ; the maximum is 0.5 per cent. per $\mathrm{cm}$.

4. Under optimum conditions six hours elapse before hydrotropic reaction is visible in roots. A presentation period could not be determined.

5. The hydrotropic sensitivity of roots resides chiefly in the tip, but also to a lesser degree above the root-tip.

6. Two factors determine the reaction of the root to a hydrotropic stimulus; one mechanical and the other vital. The intensity of the reaction varies inversely as the former and directly as the latter. When the stimulus is weak, the vital factor predominates; when too intense (above the maximum) the mechanical factor determines the reaction.

7. Hydrotropism is not a special case of traumatropism, but is probably equivalent to osmotropism.

Sheffield Scientific School.

\section{BIBLIOGRAPHY.}

Those works marked with an asterisk (*) were not obtainable in the original.

1. Bonnet, Ch. (1754): Euvres d'histoire naturelle. Vol. ii. Recherches sur l'usage des feuilles. Paris.

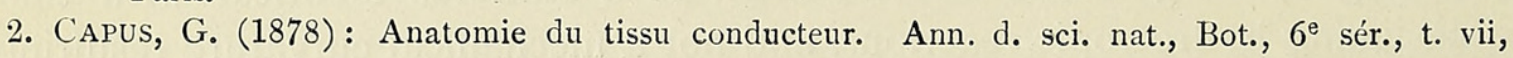
pp. 209-9I.

3. Ciesielski, Th. (1871): Untersuchungen über die Abwärtskrümmung der Wurzel. Cohn's Beitr. z. Biol. d. Pfl., Bd. i ${ }^{2}$, pp. 1-3, Pl. I, Figs. I-5.

4. Darwin, Ch. (1880): Power of Movement in Plants. London.

5. DARWIn, E. (1800): Phytologia; or the Philosophy of Agriculture and Gardening. London.

6. Detlefsen, E. M. (1881) : Über die von Ch. Darwin behauptete Gehirnfunktion der Wurzelspitzen. Arb. d. bot. Inst. in Würzburg, Bd. ii, pp. 627-47.

1 Cf. Porodko, Über den Chemotropismus der Pflanzenwurzeln, Jahrb. f. wiss. Bot., Bd. xlix, I9II, p. 347, Tabelle 17 . 
7. DODART ${ }^{*}(\mathbf{1 7 0 0})$ : Sur l'affection de la perpendiculaire remarquable dans toutes les tiges, dans plusieurs racines, et autant qu'il est possible dans toutes les branches des plantes. Hist. d. l'Acad. roy. d. sci., pp. 6I-4. Cited from Mém. d. l'Acad. roy. d. sc., t. xlvii.

8. Duchatre (1856): Influence de l'humidité sur la direction des racines. Bull. de la Soc. bot. de France, t. iii, pp. $5^{8} 3-9$ I.

9. Duhamel, H. L. (1758): Physique des arbres. Paris.

10. Dutrochet, H. (1824): Physiologische Untersuchungen ïber die Beweglichkeit der Pflanzen. Übersetzt von Nathansohn. Ostwald's Klassiker der exacten Wissenschaften, cxliv.

11. Eckerson, S. (1914): Thermotropism of Roots. Bot. Gaz., vol. lviii, pp. 254-63.

12. Elfving, * Fr. (1890): Über physiologische Fernwirkung einiger Körper. Commentationes variae univers. Helsingfors. Cited from Steyer (31).

13. $(1893)$ : Zur Kenntniss der pflanzlichen Irritabilität. Öfvers. af Finska Vetensk. Soc. Förhandl., vol. xxxvi, pp. 77-85. Cited from Bot. Centralbl., Bd. lix, p. I79 (1894).

14. Errera, L. (1892): On the Cause of Physiological Action at a Distance. Ann. of Bot., vol. vi, pp. $373-5$.

15. $(1906)$ : Sur l'hygroscopicité comme cause de l'action physiologique à distance découverte par Elfving. Rec. Inst. bot. Bruxelles, t. vi, pp. 303-4.

16. Hooker, H. D., Jr. (1914) : Thermotropism in Roots. Plant World, vol. xvii, pp. I35-53.

17. Johnson, H. (1829): The Unsatisfactory Nature of the Theories to account for the Descent of the Radicles in the Germination of Seeds shown by Experiments. Edinburgh New (Jameson's) Philos. Journ., vol. vi, pp. 312-17.

18. Jost, L., and Stoppel, R. (1912): Studien über Geotropismus. II. Zeitschr. f. Bot., Bd. iv, pp. 206-229.

19. Keith, P. (1815): On the Development of the Seminal Germ. Trans. Linn. Soc., vol. xi, pp. $252-69$.

20. Knight, Th. (1811): On the Causes which influence the Direction of the Growth of Roots. Philos. Trans. Roy. Soc., London, vol. ii, pp. 209-I9.

21. Lefébure, * E. A. (1801): Expériences sur la germination des plantes. Strasbourg. Cited from Molisch (24).

22. Mer, E. (1881) : De l'hydrotropisme des racines. Bull. Soc. Bot. de France, t. xxviii, pp. I I 5

23. Miyoshi, M. (1894) : Über Reizbewegungen der Pollenschläuche. Flora, Bd. lxxviii, pp. 76-93.

24. MolisCH, H. (1883) : Untersuchungen iiber den Hydrotropismus. Sitzungsberichte k.-k. Akad. Wien, Bd. lxxxviii, pp. 897-943, pl. I.

25. Pfeffer, W. (1894): Cited from Rothert (26), p. 208.

26. Rothert, W. (1894) : Die Streitfrage über die Funktion der Wurzelspitze. Flora, Bd. Ixxix, pp. $179-218$.

27. SACHS, J. V. (1872): Ablenkung der Wurzeln von ihrer normalen Wachstumsrichtung durch feuchte Körper. Arb. d. bot. Inst. in Würzburg, Bd. i, pp. 209-2 2, Fig. 3.

28. - (1879) : Über Ausschliessung der geotropischen und heliotropischen Krümmung während des Wachstums. Arb. d. bot. Inst. in Würzburg, Bd. ii, pp. 209-25.

29. Singer, M. (1903) : Über den Einfluss der Laboratoriumsluft auf das Wachstum der Kartoffelsprosse. Ber. bot. Ges., Bd. xxi, pp. I7 $75^{-80}, \mathrm{Pl} .9$, Figs. $a-c$.

30. Sperlich, A. (1908): Zur Entwicklungsgeschichte der Stolonen von Nephrolepis. Flora, Bd. xcviii, pp. 34I-6I, Pl. 8, Figs. I-7.

31. Steyer, K. (1901) : Reizkrïmmungen bei Phycomyces nitens. Dissertation. Leipzig.

32. Van Tieghem, Ph. (1869) : Recherches physiologiques sur la végétation libre du pollen et de l'ovule. Ann. d. sc. nat., Bot., $5^{\text {e }}$ sér., t. xii, pp. 31 2-28.

33. $(1876)$ : Sur le rôle physiologique et la cause déterminante de la courbure en arcade des stolons fructifères dans les Absidia. Bull. de la Soc. bot. de France, t. xxiii, pp. 56-59.

34. Voechting, H. (1902): Über die Keimung der Kartoffelknollen. Bot. Zeit., Bd. 1x, pp. 87-I I4. 35. Wiesner, J. (1881): Das Bewegungsvermögen der Pflanzen. Eine kritische Studie über das gleichnamige Werk von Ch. Darwin nebst neuen Untersuchungen. Wien.

36. Wortmann, J. (1881): Ein Beitrag zur Biologie der Mucorineen. Bot. Zeit., Bd. xxxix, pp. 368-74, 383-7. 


\section{$2 \mathrm{BHL}$ Biodiversity Heritage Library}

Hooker, Henry Daggett. 1915. "Hydrotropism in roots of Lupinus albus." Annals of botany 29, 265-283.

https://doi.org/10.1093/oxfordjournals.aob.a089544.

View This Item Online: https://www.biodiversitylibrary.org/item/243629

DOI: https://doi.org/10.1093/oxfordjournals.aob.a089544

Permalink: https://www.biodiversitylibrary.org/partpdf/320061

\section{Holding Institution}

Smithsonian Libraries

\section{Sponsored by}

Biodiversity Heritage Library

\section{Copyright \& Reuse}

Copyright Status: Not in copyright. The BHL knows of no copyright restrictions on this item.

This document was created from content at the Biodiversity Heritage Library, the world's largest open access digital library for biodiversity literature and archives. Visit BHL at https://www.biodiversitylibrary.org. 